\title{
Non-canonical Arabic Detective Fiction: The Beginnings of the Genre
}

\author{
BASILIUS BAWARDI (Bar Ilan University) and \\ ALIF FARANESH (Oranim College)
}

\begin{abstract}
The focus of this paper is Arabic detective fiction, which began in the late $19^{\text {th }}$ and early $20^{\text {th }}$ centuries, thanks to the broad-scope enterprise of translations, and the subsequent development of an authentic Arabic detective literature in the early 1960s. This paper traces diachronically the emergence of this popular genre at an entirely non-canonical level, in Egypt in particular, and examines its thematic characteristics. The paper also examines the causes of the lack of canonical detective literature until the early $1980 \mathrm{~s}$. It argues that Arabic detective literature, canonical and non-canonical alike, is a true reflection of the power relations and the social, political and cultural struggles in the Arab world. It further claims that Arabic detective literature is one of the most important literary strata in modern Arab literature, through which we can clearly discern changes in values and esthetics in modern Arab society, and examine the relations between money and ruling power in Egypt as a mirror of the entire Arab world and the connection between literature, preservation and the undermining of Arab law and social order.
\end{abstract}

Key words: Non-canonical Arabic detective writing, Arabic popular literature, Detective fiction, Crime fiction.

\section{Preface}

This article examines the historical development of the genre of non-canonical Arabic detective fiction, mainly in Egypt. ${ }^{1}$ It traces the milestones in the development of this genre from the early $20^{\text {th }}$ century to the present day. This diachronic overview of most of the series through which Arabic detective fiction was published-both translations and original

1 Non-canonical literature refers to genres that were not accepted as part of mainstream literature and remained on its margins. Works of this kind were treated with disdain and thus rarely included in academic research. Reuven Snir stresses the point that most genres that make up the popular noncanonical prose are limited, ignored and suffers from a lack of interest, as is reflected in scientific studies as in the West. Thus Snir describes the state of works belonging to genres not recognized as canonical in modern Arabic literature such as detective stories and science fiction. He also relates to their content saying that 'being sub-canonical is not just a question of the language of the writing [i.e. fuşhà vs. 'ämmiyya] but also of topic and content. Research and criticism in the Arab world has almost completely ignored the sub-canonical sectors, and even when it does relate to them, it is in most cases for extra-literary motives, mainly folkloristic and national, such as, for example, seeking roots or trying to mold a national identity and disprove claims that negate it' - SNIR 1994: 55. Compare also with SNIR 1998: 87-121. 
writing-paves the way for a more comprehensive examination of this genre, which has been largely ignored by academic research, despite a very extensive readership both in Egypt and elsewhere in the Arab world. The article focuses more on the historical aspect of this genre, as a first step in laying the foundations for a wider, macro-perspective approach, in order to reveal the tremendous quantity of Arabic detective texts that exist to this day. We believe that the lack of critical discourse, the paucity of research, and the neglect of the genre among the literary establishment are the main reasons for the terminological confusion between pure (police) detective stories, espionage and science fiction, and the lack of a methodical framework that might have contributed greatly to the shaping of this genre. Moreover, the article gives an overview of the main issues and themes conveyed to the readers of the Arabic crime fiction series. Our thematic perspective sheds light on the ensemble of social, political and nationalist messages that these series contain, and provides an opportunity to get an initial glimpse of the cultural content they disseminate. ${ }^{2}$

As in Western literature, the genre is usually classified/dealt with under the umbrella of popular culture. This term assigns/ascribes to it the characteristics of a literature that reflects, or is supposed to reflect, a broad popular experience. This experience touches the daily lives of people who are part of a specific world order and set of values. According to theoretician Stuart Hall, popular culture includes two basic concepts, which together comprise its essence: inclusion and resistance. Literature is typically dynamic and so includes a broad range of values, types of writing and human experiences in many areas, and to the same extent, opposes the existing hegemonic values, constantly trying to establish itself parallel to that order or at its expense. ${ }^{3}$

In light of the above, this paper proves that Arabic detective literature in its noncanonical format adopts the first principle, i.e., inclusion. However, like Western detective literature, it does not oppose the existing order, values and politics. On the contrary, this paper actually shows it to be an important tool for preserving the ruling hegemony. Hence, and based on the theories of Horkheimer and Theodor Adorno and the Frankfurt School, which distinguishes between "high" and "low" culture, this paper sees non-canonical Arabic detective literature as part of what Adorno and Horkheimer call the "culture industry' that reconciles with, and even preserves, existing conditions. ${ }^{4}$ In contrast, later canonical Arab detective literature adopts both principles, and indeed strives to undermine the existing order.

2 Despite the scarcity of research on this genre in modern Arabic literature, it is important to note the few studies that do exist in the Arab world and in the West. These are presented here chronologically: PATTERSON-ISKANDER 1987: 118-131; MALTI-DOUGLAS 1988a and 1988b; CAWELTI 1976: 82-83; ALLEN 1984: 51-60; PATTERSON-ISKANDER 1993: 75-78; SNIR 1994: 49-80; SNIR 1998: 87-121; GonZALES-QuiJANO 1998; JACQUEMOND 2003; Selim 2010; GuTH 2016: 6; Colla 2005: 417-443; SMOLIN 2013; LOPEZ 2005: 371-397. In the Arab world we found a small number of sources who had studied the genre, see SHARSHĀR 2003; SUlAYMĀN 2008; Fușūl 2009, 76; Al-Qāfila, 46 (SeptemberOctober, 2012); Al-Majalla al-'Arabiyya 2011: 412. We also found that the journal al-Dawha (Doha, Qatar) devoted issue 8 in June 2008 to the question of the lack of detective novels in Arabic literature. See also the book of HALĪFī that collects some of the articles of Fușūl, in HaLİFĩ 2012; SAGASTER 2016.

3 El-HAMAMSY 2013; DiMAGGIO 1991: 373-397.

4 ADORNO 2001; ADORNO 2007: 34-43.

jais • 18 (2018): 23-49 
These Western theories anchored this paper and served as a research tool with which to analyze the non-Western detective literature. Among these theories is also Even Zohar's Polysystem Theory, on the basis of which one can explain the process during which Arabic detective literature moved from the margins to the center. According to Even Zohar, what was considered to be at the margins of a literary system in a certain period may subsequently shift and win a place at the heart of this system. Almost the only reference to Arabic detective text was in the translation of Western detective works as part of the popular literature. This is also precisely the reason why these works were ignored by the literary establishment. The theory explains the process of the transition in that the exclusive treatment of the elements comprising the literary center might lead to extreme changes in the literary experience because it ignores the movement and interactions between margins and center. In the end, this state of affairs will yield a completely opposite result: The center element will disappear, and its place will be filled by elements thought marginal until then. For example, poetry lost its central status in the literary center, and the detective text moved towards the center. ${ }^{5}$

\section{The development of non-canonical modern Arabic detective fiction}

As we shall see, the writing of non-canonical modern Arabic detective fiction went through two phases: translations from Western crime fiction, and original Arabic works. The transition from translation to original writing was not a clear-cut change, but rather a gradual and parallel process. The translations often suffered from a lack of professionalism and haste and contained many errors both in content and in language. This damaged the quality of the translated work and, consequently, also the genre as a whole.

\subsection{Stage 1 - Translation as a first encounter-the origins}

The first encounter of Arabic literature with written detective literature, and more precisely, with the genre of detective narrative, came through translation, as was the case also with other non-canonical genres such as science fiction. On this point Snir writes: "Like canonical literature, sub-canonical translated literature constitutes a channel of contact with other literatures and is a source, albeit an indirect one, of changes to the poetics of Arabic literature." This is the reason why Egyptian and other Arab writers, from Tawfĩq al-Hakīm to 'Șun'allāh 'Ibrāhīm, remember to have read in their childhood and adolescence cheap editions of Arsène Lupin, Edmond Dantes, Sherlock Holmes and Rocambole. ${ }^{7}$

The most famous character in detective fiction was that of the charming Arsène Lupin, created by French author Maurice Leblanc (1864-1941), so much so that Majdī Yūsuf, one of the few scholars to review the translations of this genre, said:

Hardly any Arab intellectual began his journey without reading the detective stories of Arsène Lupin, which gave the translations of these novels a high status that only

\footnotetext{
5 EVEN ZOHAR 1990: 9-26

6 SNIR 1994: 59.

7 SELIM 2010
} 
a fool would ignore in the history of modern Arabic literature and culture, so much so that one may determine a period in the history of every Arab reader called "the Arsène Lupin phase.",

It was 'Abd al-Qādir Hamza who first translated the adventures of Arsène Lupin into Arabic with the adventure entitled 'Gentleman-Cambrioleur'. The translation appeared in 1910, three years after the original edition in French (1907), in the journal Musāmarāt alShabāb (Youth Nightlife), which was published in Cairo between 1904 and 1911. ${ }^{9}$

Also translated were Agatha Christie's novels and the Sherlock Holmes novels of Sir Arthur Conan Doyle (1859-1930). ${ }^{10}$

Arabic readers were also familiar with the character of Simon Templar (The Saint), created by author Leslie Charteris (1907-1993) ${ }^{11}$ as well as Charlie Shane, whom the Arabic readers knew well from the many novels translated in the Riwāyāt 'Ālamiyya (Universal Novels) series published in Cairo, ${ }^{12}$ as well as the character of Mike Shine, whom Arabic readers knew particularly well thanks to several popular series of detective fiction published in Beirut, and those of the famous English detective novelist Edgar Wallace (1875-1932).

The name of 'Abd al-'Azīz 'Amīn is mentioned as one of the popular translators of that period. He translated and adapted many Western detective works of fiction and established the weekly Riwāyāt al-Jayb (pocket novels). The names of Țānyūs 'Abduh and 'As'ad Dāghir are also mentioned as active translators of that time. Even as late as 1981, we still observe similarly unreliable customs on the side of the translators that led to much confusion regarding the matching of translations with the original texts. A clear example of this is the work of one of the main translators, 'Abd al-'Azīz 'Amīn, which was often confusing and lacking in transparency. In one of the pocket novels he published, Khattimat al-Ma'sāh (The End of the Tragedy), the front cover of the book says "Agatha Christie," but the inside cover gives 'Abd al-'Azīz 'Amīn not as the translator, but as the author. This is an indication of how slack and inaccurate the publishers were and how little framework there was to supervise the publishers. ${ }^{13}$

'Abd al-'Azīz b. 'Abd Allāh and Ḥāfiz Najīb, who were not recognized as pioneers of Arabic detective fiction because of doubts about the originality of their work, which looked like translations that had undergone serious 'Arabization', published so many books that Najīb was nicknamed the "Egyptian Arsène Lupin," or the "swindler author" (al-'Adīb almuhtāl) because of all the books he translated and then published with no mention of the original Western author's name.

Al-Jundi claims that the translation process was supposed to play a positive role in transmitting great literary works into Arabic in order to strengthen Arabic literature, but

\footnotetext{
8 YŪSUF 1994: 7.

9 SELIM 2010.

10 YŪSUF 1994: 41-42.

11 YŪSUF 1994: 41.

12 YŪSUF 1994: 49-53.

13 See KRĪSTī 1981.
}

زа丿 • 18 (2018): 23-49 
this process deviated from its path and purpose because of the colonial hegemony and cultural influence of France and Britain. It is perhaps here that we find the secret behind this deviation of the translation process from its main purpose and its change into a tool to amuse and satisfy the readers. ${ }^{14}$ We believe that this opinion is not based on objective facts or evidence showing that translations were introduced with the intention to damage Arab culture. It is al-Jundī's personal opinion, and a deeper investigation of the cultural milieu of that period reveals that the people in charge of translation simply preferred the cheaper and economically more worthwhile. The unaesthetic format of these translated books, their linguistic level and even the type of paper they were printed on, all point to financial considerations rather than a Western colonialist plot. Furthermore, other genres considered more canonical, such as novels, short stories and drama, were translated in the same cheap manner.

Thus we see that at the beginning of the $20^{\text {th }}$ century, Arabic literature, the Arab writer and the Arab reader all encountered detective fiction in its various forms, such as the novel, the short story, the adventure series, and so forth, where the flow was one-directional: from West to East, by way of translation, which for the most part did not adhere to our modern rules of professional translation or its ethics. Moreover, these translations were often deemed suspect both by Arab intellectuals and by the man in the street. These suspicions were mainly expressed in the notion that the colonialists were using them to impose their foreign culture and deprive the Arab and Islamic nation of its values and heritage. ${ }^{15}$ This might explain the unfavorable attitude, to put it mildly, adopted by academics of Arabic literature towards non-canonical literature in genera ${ }^{16}$ and detective fiction in particular, as well as the shaky status in which this genre found itself compared to other genres of modern Arabic literature. However, these suspicions did not halt the translation industry for detective works, which continued for over six decades. The main damage caused to the genre was the lack of help in getting it accepted into official mainstream literature.

\subsection{Stage 2 - Original Arabic detective fiction}

In his book al-Dhākira al-Mafqūda (The Lost Memory), 'Ilyās Khūrī says:

Arab modernism has managed to borrow from and draw on all the signs of Western modernity, from the system of governance to the police and modern art forms. But one art form has remained impossible and rebellious and couldn't be borrowed. That is the detective story. ${ }^{17}$

He is echoed by al-Sa'dī, who, while showing the presence of crime in three Arab novels, illustrates this saying:

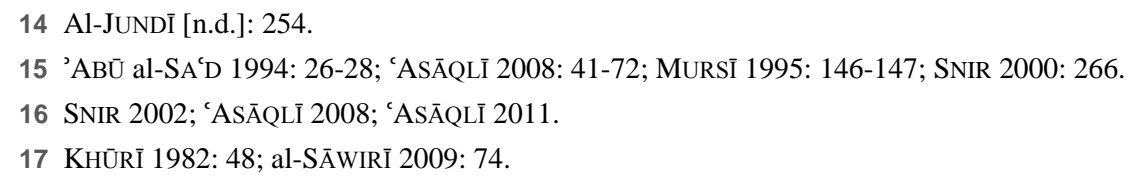


When we relate to this genre of novels, it is important to mention that although they start with the crime of murder, they do not contain the essential techniques and thematic aspects that allow us to consider them detective stories. ${ }^{18}$

However, while translation of detective works continued to flourish, with many works from the West finding their way to the translator's desk and from there to the readers, adolescents, for the most part, the first significant change in regard to Arabic detective fiction occurred, signaling the start of the second phase-writing and publication of original detective fiction in Arabic. Snir comments: 'thus we can mark the rise in importance of original detective fiction as opposed to translated detective fiction'. ${ }^{19}$

The switch from translation to original writing in this genre took place at the noncanonical level which included mainly detective fiction intended for young readers. All the respective original series share common features and a uniform structure and amazingly similar order - they are all full of action, suspense, pursuits and violence. In this field, we may remember a number of milestones:

\subsubsection{First juncture}

The first appearance of original detective stories and mysteries in Arabic ${ }^{20}$ which were not translated from Western literature ${ }^{21}$ seems to have been in Egypt in 1968 in the form of a series of mysteries under the heading of Detective stories for children. The first adventure, ${ }^{22}$ Al-Kūkh al-Muhtariq (The Burning Cottage), was written by Maḥmūd Sālim. ${ }^{23}$ Every pocket book in the series included three different descriptions of its content: on the front cover in small letters beneath the heading Detective Stories for Children (Qișas Bülisiyya), the title always began with: The Mystery of... (Lughz...). Then, on the inside cover it said: Adventure no. $n$. It is almost always noted that these were adventure stories written for youth rather than for the adult reader. ${ }^{24}$ At any rate, we believe that the multiple names and the parallels of the subtitles on each pocket book reflected confusion among the authors and publishers, perhaps because of the novelty of the attempt at original writing of the genre. In addition to this series, there were many others which attracted millions of Arabic readers in Egypt and the rest of the Arab world. The overview below of the plethora

18 Al-SAADI 2012: 2

19 SNIR 1998: 87-121; SNIR 1994: 59.

20 SHARSHĀR 2003: 33.

21 CACHIA 1990: 172-173.

22 Prior to these adventures, there were a number of very short detective riddles by Mahmūd SĀLIM (see note 23). The first of these was Lughz al-Zujäj al-Maksür (The Riddle of the Broken Glass).

23 The Egyptian writer Maḥmūd SĀLIM (1929-2013) is considered to have played a key role in establishing the genre of original detective fiction in modern Arabic literature. He published his adapted and Arabized (ти'arrab) detective fiction stories in 1968, in Majallat Samì (The Entertaining Companion Magazine) with Dār al-Hilāl, Cairo, edited by Nādiyā NASH'AT. He played a decisive role in expanding the inventory of literary devices in Arabic narrative fiction, enriching the literary experience and offering a renewed perspective on this literature and the conceptual and textual grids. For more on the author, see SAAD 2013 and PATTERSON-ISKANDER 1993:118-131.

24 See for example, SĀLIM [n.d.] $a$, [n.d.] $b$, [n.d.]c, [n.d.]d. 
of adventure stories and mysteries that quickly emerged in the Egyptian markets uncovers for the first time the start of the writing process of the authentic Arabic detective narrative in new Arabic literature, following the long-term success of the translated series in those same markets.

- al-Mughāmirūn al-Khamsa (The Five Adventurers): Muhibb, Lūza, Nūsa, 'Āṭif, Takhtakh, by Mạ̣mūd Sālim.

- al-Mughāmirūn al-Thalātha (The Three Adventurers): 'Āmir, 'Ālya, 'Ārif, and the dog Murjān, by 'Abd al-Raḥmān Ḥamdī.

- al-Mughāmirūn al-Thalātha (The Three Adventurers): Muḥsin, Hādiya, and Mamdūḥ, by Rajā' 'Abdallāh.

- al-Mughāmirūn al-Thalātha (The Three Adventurers): Yāsir, Hāla, and Hishām, by Mușțafà 'Aḥmad Mușțafà

- al-Mughāmirūn al-'Arba'a (The Four Adventurers): Farīq al-'Adhkiyä'’ (The Smart Ones): Karīm, 'Alyā', Rāmī, Shādī, by Hishām al-Șayyād.

- al-Mukhbirūn... al-'Arba'a (The Four Informants): Khālid, Mushīra, Filfil, Ṭāriq, and the $\operatorname{dog} \mathrm{Sab}^{c}$, by Hudà al-Sharqāwī.

- al-Waḥda Raqm 14 (Unit Number 14): Wā’il, Rihām, 'Aḥmad, Dālya, and 'Amr, by Hamdī 'Abbās.

- al-Taw'amān (The Twins): Ra'ūf and Randa, by Mușțafà Hamām. ${ }^{25}$

In the mid-seventies ${ }^{26}$ Mu'assasat Dār al-Hilāl published a new series entitled Majmū'at alShayāținn al-13 lil-Shabāb (The 13 Devils Group for Youngsters), written by Mạmū̃d Sālim under the heading Kutub al-Hilāl lil-'Awlād wal-Banāt (al-Hilāl Books for Boys and Girls.

The group consisted of 13 boys and girls from various Arab countries ${ }^{27}$ whose goal was to protect the great Arab homeland, "and they stood strong against the plots directed against the Arab homeland," as it stated in each pocket book. ${ }^{28}$

\subsubsection{Second juncture}

The second important juncture in the history of Arabic detective fiction (and the history of other non-canonical genres such as science fiction in modern Arabic literature) in Egypt

25 Thus we see within the series Qișaș Bülissiyya lil-'Awläd (Detective Stories for Children) a diversity in the groups of adventures themselves, and in the authors. For further reference, see Hamdī MușṬAÀ [n.d.].

26 The year was deduced through simple mathematical comparison: adventure \#96 came out in February 1984. Each pocket book stated that 12 were published each year on the $5^{\text {th }}$ of each Gregorian month (i.e. one pocket book a month). Hence, by simple calculation: $96 \div 12=8$, which brings us to 1976 .

27 'Aḥmad from Egypt (the chief), 'Uthmān from Sudan, 'Ilhām from Lebanon, Hudà from Morocco, BūंMīr from Algeria, Miṣbāh from Libya, Zubayda from Tunisia, Fahd from Syria, Khālid from Kuwait, Rīmā from Jordan, Qays from Saudia Arabia, Bāsim from Palestine, Rashīd from Iraq. In addition, there is the Number Zero, the mysterious chief whom nobody knows anything about and who is probably a member of the Egyptian security forces.

28 SĀLIM 1984, SĀLIM 1999 
and the Arab world in general, occurred in 1984 when Al-Mu'assasa al-'Arabiyya alHadītha (The Modern Arabic Institute) ${ }^{29}$ began publishing a variety of series dealing with science fiction, detective science-fiction, detective adventure stories and other series ${ }^{30}$ that became tremendously successful and urged/encouraged the publishers to put out more new series with many nuances and innovations. ${ }^{31}$

Thus al-Mu'assasa al-'Arabiyya al-Haditha began publishing the new series in the following chronological order:

1. Rajul al-Mustahīl (The Man of the Impossible - an adventure series from the files of the Egyptian intelligence service. The first pocket book was called al-Ikhtifä al-Ghämid (The Mysterious Disappearance). ${ }^{32}$

2. Milaff al-Mustaqbal (The Future File) - detective adventures in the realm of science fiction (a very new combination), written by Fārūq Nabīl. ${ }^{33}$

3. Küktīl 2000: Mā Warā’al-Tabī'a (Cocktail 2000: the Supernatural) - horror novels, action and science fiction stories, by Fārūq Nabīll. ${ }^{34}$

4. Mā Warā' al-Tabī'a (The Supernatural) - horror stories written by 'Ahmad Khālid Tawfïq, each pocket book title beginning with 'Usțürat... (The Legend of...). ${ }^{35}$

5. Sāfārì Mughāmarāt fì al-'Adghāl (Safari Jungle Adventures), in each of which the hero 'Alä' encountered and defeated evil forces. ${ }^{36}$

6. Fantazyā (Fantasia) - adventures in imaginary places, where in each adventure 'Abīr meets a famous detective from a well-known Westerm detective series and solves a mystery. ${ }^{37}$ This series is very interesting because it indirectly reviews Western detective series by mentioning various sleuths (mukhbirūn) such as Sherlock Holmes and Poirot. What is noteworthy is that in one of the adventures, the heroine 'Abīr meets up with the heroes of the series entitled The Five Adventures, Muhibb, Lūza, Nūsa, 'Āṭif, and Takhtakh, by Maḥmūd Sālim, and thus treats them as classics of the genre of the same stature as Holmes or Poirot. ${ }^{38}$

29 Hamdī MUȘŢAÀ, who founded it in 1960 and published reference and revision books for schoolchildren in Egypt under the odd name of Siläh al-Tilmīdh (The Student's Weapon). In 1984 he decided to expand the fields of his publications, summoned two young authors-Nabīl FĀRŪQ and Sharif SHAWQ - and asked them to start writing novels [sic] because he wanted, as he said, to publish "100\% pure Egyptian novels, with no guilt of copying or quoting (from the West)." <www. rewayatnet.net>, accessed 30 March 2015.

30 SĀLIM 1984, SĀLIM 1999.

31 On this Snir says: "The same publisher put out two series of the same type, each of which contained dozens of novels; an indication of the broad scope of the reading circle and of tremendous monetary income." SNIR 2000: 270-274.

32 FĀRŪQ [n.d.] $b$.

33 FĀRŪQ [n.d.]d.

34 FĀRŪQ [n.d.] $h$.

35 TAWFĪQ [n.d.]a.

36 TAWFĪQ [n.d.]b.

37 TAWFĪQ [n.d.]c.

38 TAWFĪQ [n.d.]d. 
7. Sayf al-'Adāla (The Sword of Justice) - stories of resistance to evil and establishing justice, written by Nab̄il Fārūq. ${ }^{39}$

8. Färis al-'Andalus (The Knight of Andalusia) - stories of brave adventurers from the time of the Arabs in Andalusia, described as "acts of Arab bravery in the most difficult period the Arabs underwent in Andalusia," written by Nabīl Fārūq. ${ }^{40}$

9. 'Idārat al-'Amaliyyāt al-Khāșșa (Special Ops Administration - Office 19) - combining adventure, fiction and commando missions; a series of detective novels from the realm of science fiction, by Sharīf Shawqī. ${ }^{41}$

10. Oscar - adventures in comic book format, described on the inside back cover as "Egyptian and European stories and illustrations that will remain in your hearts and minds, since these are the strongest comic adventures for youngsters in the world." ${ }^{42}$ And on the inside page it says:

A new series that offers you, for the first time in the history of Arabic literature, the art of the comic book story that contains a lightness of expression and phrasing, the beauty of pictures and the elegance of drawing. This is a pioneering series offered to you by al-Mu'assasa al-'Arabiyya al-Hadītha, written by author-illustrators and Egyptian painters, and the best of world artists. The first buds of a new genre both in literature and in art that adds to the Arabic library, and to young Arabs in order to bring them the modern spirit and contemporary art in a new developed modern format that simultaneously provides both education and pleasure. It is a series of daring through which (Egyptian pocket novels) break into a new world full of action, enjoyment, stimulation and beauty. A prestigious series that raises one's level of thinking and imagination, encouraging the Arab mind and taste in an effort to climb up a step, to move on towards the slogan that (Egyptian pocket novels) coined for its inception: 'We publish the best books'. This series stresses the fact that you are an educated person in terms of what you read and what you see. ${ }^{43}$

In the list of editors it says the following: "With the support and assistance of Nabīl Fārūq, supervision Ḥamdī Mușțafà. " ${ }^{44}$

11. Panorama, a magazine with adventures and correspondence between the readers and the author Nabīl Fārūq (illustrations: 'Ismā̄̄îl Diyāb; editor: Ḥamdī Muștafà), described as "a book within a magazine, and a magazine within a book, a new series offering a broad digest of literature, culture and art that the publisher of Riwayyāt Missiyya lil-Jayb [Egyptian pocket novels] used to present to the youth in a new and special format, in a simple, modern style, and is a comprehensive picture of everything you like and

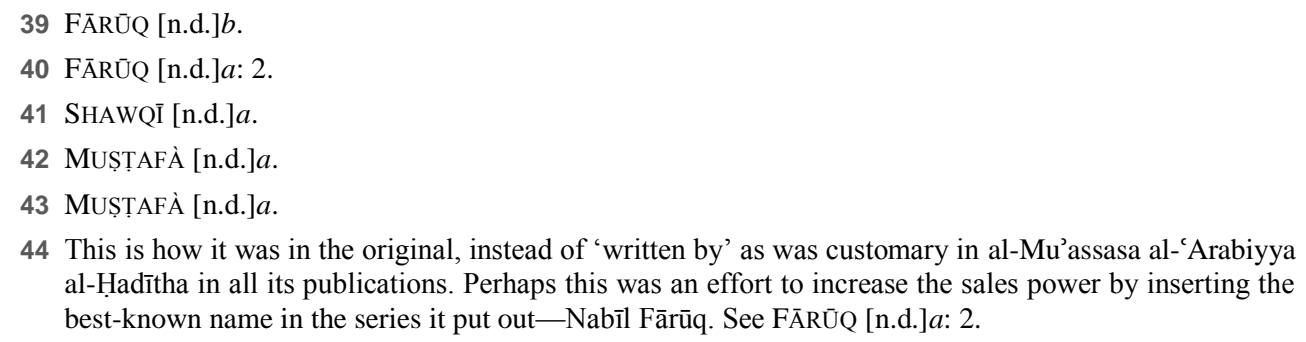

44 This is how it was in the original, instead of 'written by' as was customary in al-Mu'assasa al-'Arabiyya al-Haditha in all its publications. Perhaps this was an effort to increase the sales power by inserting the best-known name in the series it put out-Nabīl Fārūq. See FĀRŪQ [n.d.]a: 2. 
everything that attracts you at the end of the $20^{\text {th }}$ century. It is a panorama of the future and of the youth, all youth." ${ }^{45}$

12. Adventures of 'Ayn $x 2$, described as "interesting detective mysteries for youth," written by Nabīl Fārūq and supervised by Ḥamdī Muștafâa. ${ }^{46}$

13. Nova, a series of science fiction stories from the future, by Ra'ūf Wașfi. ${ }^{47}$

Page $\mid 32$ 14. Flash, a diverse series containing stories, jokes, crossword puzzles, detective mysteries, general knowledge, adventure stories, riddles and logic games. Text and illustrations by Khālid al-Ṣaftī, supported by Dr. Nabīl Fārūq. The emphasis was on the mysterious ambience, and so each pocket book title in the series began with "The Secret of [...]". 48

15. Zoom, a diverse series containing detective mysteries, stories, jokes, crossword puzzles, riddles, general knowledge, a 'wonder of numbers' corner, science fiction and more. ${ }^{49}$ Illustrations by 'Abd al-Ḥalīm al-Ḥașrīi, text by Dr. Nabīl Fārūq. ${ }^{50}$

16. Smash, containing a diverse collection of comics, jokes, crosswords, general knowledge, riddles and logic games, drawings and comments on sports, plays, an 'open your heart' column, where readers sent the editors their stories, problems and dilemmas, and he would respond with comments and suggestions, and more. Those in charge described it as an "illustrated series," written and drawn by Khālid al-Șaftī. ${ }^{51}$

17. The Series of Special Editions (Arabic title) is a collection of several unusual adventures for the heroes of the series of Rajul al-Mustahill (The Man of the Impossible) and Milaff al-Mustaqbal (The Future File). There were editions entitled 'Very Special Edition ${ }^{52}$ in addition to an interactive website. ${ }^{53}$

18. Rihalāt al-Sindibād (Sinbad's Travels), an adventure series that combines science fiction, a fairy tale atmosphere and a hint of history. There is mystery, action, deception and movement, written by Nabīl Fārūq. Only six issues were ever published.

19. Al-'Amīl al-Sirrī Șifr Șifr Șifr (Secret Agent 000), a series for youth written by Nabīl Fārūq, with only seven issues.

20. Harb al-Jawāsīs (The War of the Spies), espionage adventures written by Nabīl Fārūq, with 11 regular and 6 special issues.

21. Mughāmarāt Flāsh Blūs (Flash Plus Adventures) - ironic adventures for children.

22. Super Oscar series - keeping the same ambience as Oscar, but with more action.

23. 'Ālam al-Jāsüsiyya, stories taken from Intelligence files.

24. Mughāmarāt Bilya al- 'Ajīb (The Adventures of Amazing Bilia), adventures for children written by 'Abd al-Ḥamīd 'Abd Allāh Maqșūd.

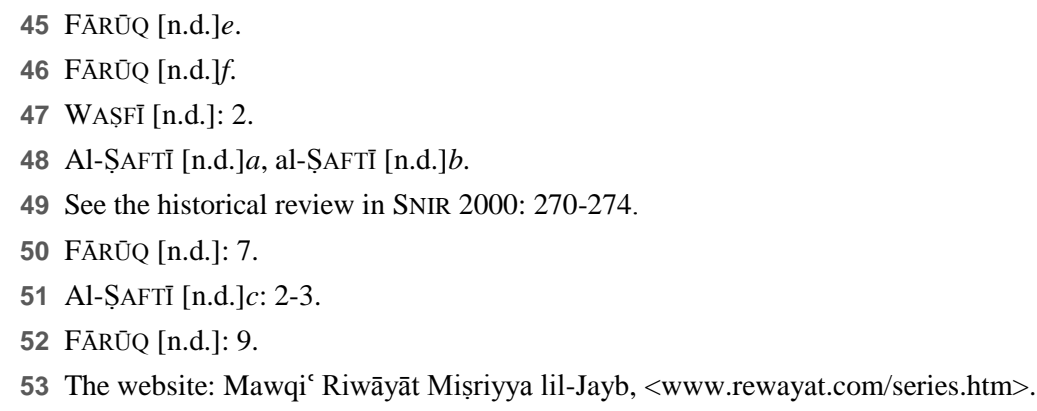


25. Mughāmarāt Tīfa (The Adventures of Tīfa), adventures for children written by a group of writers.

26. Nìmū al-Jarī' (Daring Nīmū), adventures for children written by 'Abd al-Hamīd 'Abd Allāh Maqșūd.

27. Al-Mughāmir (The Adventurer), an adventure series written by Bāsim Șalāḥ al-Dīn.

28. Al-Maktab Raqm 17 (Office No. 17 - Special Ops Administration), detective adventures written by Muḥammad Sulaymān 'Abd al-Mālik.

29. 'Ālam Gharīb (Strange World), stories of alien visits to Earth, written by Jalāl 'Abd alFattāh.

30. 'Ālam 'Ākhar (Another World), horror stories by Tāmir 'Ibrāhīm.

31. Miga (Mega), a series of adventures stories written by a group of writers.

32. Al-Șarkha (The Scream), horror stories written by Muhammad Riḍà 'Abd Allāh.

33. Trānzìt (Transit), only one issue was published entitled Invitation for One, written by Muḥammad Sulaymān 'Abd al-Mālik.

34. Hālāt Khāșsa (Special Cases), scary stories of horror and psychological battles, written by Muhammad Riḍà 'Abd. On the cover it says: "The memoirs of a psychologist fighting for his life and his sanity."

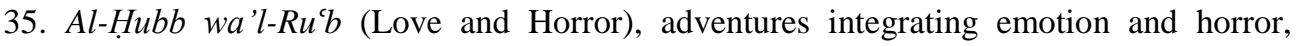
written by Sālī 'Ādil.

36. Milaffāt Yūsprīdis (The Yuspridis Files), a series that first appeared in 2011 and which had the following issues: Nahr al-Nisyān (The River of Forgetting), Hasnā’ Yūsprīdis (The Yuspridis Beauty), Tāsīlli, written by Libyan author 'Ayman bin Hamīd.

37. Masrah al-Jarima (The Theatre of the Crime) series, by Nabīl Fārūq, publisher alMu'assasa al-'Arabiyya lil-'Ibdāc', which had two issues: Jarīma fi Majlis al-Sha'b (A Crime in the Parliament) and Ightiyāl (Assassination). The heroine in these two stories is Nahīr Sālim, a pathologist who is an expert in forensic medicine.

38. Al-Farìq (The Group), adventures filled with suspense, action, pursuits and fighting, written by Nabīl Fārūq. This is a very modern series, written for al-Mu'assasa al'Arabiyya al-Hadītha. There have been two issues: Qalb al-Jahìm (The Heart of Hell), January 2014, and Silạh al-Sharr (Weapons of Evil), February 2014.

39. Commandos - Mahāmm Khațīra (Dangerous Ops... Terrifying Consequences). An action thriller series with stories of well-known conflicts between nations and hawkish groups. Edited by Jalāl 'Abd al-Fattāḥ and supervised by Ḥamdī Muștafà.

40. Taxi, a series of "crazy adventures" as the author Hasan al-Halabī describes them. The hero is "a controversial taxi driver" who comes across each crime adventures and sets out to solve it. ${ }^{55}$

41. Sallat al-Riwāyāt (The Novel Basket), a varied series containing elements from different series of different genres of suspense such as detective fiction, horror, and science fiction, written by several authors including 'Abīr 'Abd al-Rāziq. The series first appeared in 2003 and is still being published today.

54 'ABD ALLĀH, Hālat Ishtibāh, 7.

55 Al-ḤALABī [n.d.] a, al-ḤALABī [n.d.]b. 
In the writings of Nabīl Fārūq and 'Aḥmad Khālid Tawfìq a revolution occurred that went beyond any commercial interest, but was connected to a transition from non-canonical to canonical writing, in other words, a transition from the margins of literature to its center, as Snir puts it. ${ }^{56}$ And that is what happened, in our opinion, with Nabīl Fārūq and 'Aḥmad Khālid Tawfīq, the two most senior authors who wrote diverse materials for al-Mu'assasa al-'Arabiyya in enormous quantities. When they slowed the pace of writing, the various better and less well-known suspense series, such as Rajul al-Mustahīl (The Man of the Impossible), Milaff al-Mustaqbal (The Future File), Harb al-Jawāsīs (War of the Spies) etc., turned to a more canonical literary style of novels and short stories, even though the content remained connected to detective and science fiction, crime, fear and horror. The new publications are defined as "novels," have the same size as canonical novels and are displayed at the International Book Fair in Cairo which is preponderantly devoted to canonical literature. At a press conference held in the auditorium of the Faculty of Medicine at Țanțā University on January 11, 2010, Fārūq announced that he was going to stop writing for youth now and instead continue with special editions and novels, one of which is entitled 'Adham, about the hero of the Rajul al-Mustahill series, and another one, a science fiction novel, entitled Nihâyat al-' Ālam (The End of the World).

Moreover, the institution announced a contest among readers interested in writing to select those with a talent for writing and offer them one or two, sometimes even more new series, to be written in the setting of the stories and adventures such they had read when they were young, with variations in the topics and colourful innovations. The series were published under the above-mentioned umbrella series Sallat al-Riwāyāt (The Novel Basket).

In 1987, Dār al-J̄̄l in Beirut published the Mughāmarāt al-Jīl al-Būlīsiyya (Al-Jīl Detective Adventures), by Rajā' ${ }^{\text {CAbd Allāh. }}{ }^{57}$ It seems that this was smart thinking and excellent execution by Dār al-Nashr al-Lubnāniyya since it was well aware of the reality of the innovation discovered in Egypt, and thus it called on one of the writers who had written detective mysteries for children for the Dār al-Ma ārif publishing house in Cairo, to write new adventures for them to publish. The adventurers, brothers of an Egyptian father and a Lebanese mother, ${ }^{58}$ pursue delinquents and criminals in order to uncover their crimes and wrongdoings, with the help of their uncle, Col. 'Imād Dīb, an officer from Interpol.

Mughāmarāt al-J̄̄l al-Būlīsiyya is one of the series published by Dār al-Jīl in collaboration with writers from Egypt who had connections with the detective stories and adventures published by Dār al-Ma'ārif. It was considered a pioneering step in this new genre. In addition to the above series, Dār al-Jīl published the Mughāmarāt al-Jīl alDāhikika (Al-Jīl Comic Adventures), in comic book format, i.e., with cartoon-like drawings

56 SNIR 1998: 87-121. - Compare also EvEN-ZOHAR 1990 and KHOURY 2006.

57 We came across the name of the same author in the Detective Stories for Children series, published by the Egyptian Dār al-Ma ârif (Ministry of Education), and this is evidence of the close connection between these two series, both in timing and in the actual process of their appearance - once again in Cairo and Beirut - first the phase of translation and later the phase of original writing.

58 We will expand on this further in the discussion on the reasons and motives, and when referring to the current pan-Arabist orientation, sometimes quite strong, in the content of the various series and works. 
and speech bubble text ${ }^{59}$ by Rajā' 'Abd Allāh and illustrations by 'Iffat Husn̄. There is also the Mughāmarāt al-Jīl al-'Ilmiyya (Al-Jīl Science Adventures) series, again in comic book format, written alternately by 'Afāf 'Abd al-Bārī and Rajā' 'Abd Allāh, with illustrations by 'Ashraf Sa'īd, Șafwat Qāsim, 'Ibrāhīm Samra and 'Iffat Ḥusnī. In each adventure, the plot is devised as a conflict between two forces, good versus evil, where the goal of the forces of evil very often is to harm the world and destroy its order. The authors made sure to write on the back cover of each pocket book a succinct summary of the story's conflict and a brief overview of the events. An example of this appears in Adventure no. 10 of the series, entitled The War of the Metals, where it says:

Surprises in scientific progress [...] endless inventions that surpass imagination $[. .$. with man's dreams of a greater future, Good fights Evil [...] while that Evil tries to crush and destroy human happiness [...] and this sparks unimaginable and indescribable adventures [...] such as those in this story. ${ }^{60}$

Thus we see an interesting phenomenon: many Arab authors who wrote detective mysteries and adventures also wrote science fiction, an indication of a link between these two literary genres, especially at the start of original writing, and probably the result of the confusion and lack of distinction or the merging of the two. ${ }^{61}$

This also indicates the evolution in the attitude towards the genre of detective fiction as original works began to appear, expand and diversify. Likewise, there is indication of the existence of a sense of expertise in this genre that enables writers to constantly introduce innovations. Majdī Șābir, an author of children's books and detective fiction born in 1960, explains the reasons that led to publication: "No one thought or dared to publish this kind of series in the past ... [ellipses in the original] you might wonder [...] why this new series? The answer is that the reader is no doubt tired and bored after reading dozens and hundreds of detective stories and stories of suspense and violence [...] and is looking for something new.",62

As is evident from the above, the Arab writer obviously is aware, especially in the early 1990 s, of the tremendous momentum of production in this area, and concerned that the readers of this genre will get fed up with the familiar format of adventure stories they are used to reading. Therefore, it seems indicated to seek a new style and a new and attractive format that will once again draw in the readers. No wonder then that authors also seek to construct new templates of adventurers/investigators, e.g. that of comedy.

Thus in 1991, Midlayt al-Maḥdūda published a new series entitled Mughāmarāt Jum 'a wa-Shurakäih (The Adventures of Jum'a and his Partners), comic detective stories and adventures. In the first issue, which bore the title The Treasures of Guardian Shanabu, author Majdī Șābir writes to the ultimate reader: "You may be surprised and amazed once you have the first issue of this new series in your hands, and, without a doubt, the reason

\footnotetext{
59 Thus in the original. See 'ABD ALLĀH 1989.

60 'ABD al-BĀRİ [n.d.]c: back cover.

61 See SNIR 2002: 209-229.

62 ȘĀBIR 1991: introduction.
} 
for this surprise and amazement is that this is the first series of its kind-i.e., comic detective stories that you will see with your own eyes."63

It is probably safe to say that this is a clear innovation, an attempt to diversify the genre, or even to lay the groundwork for a new genre that integrates suspense and humour. It reflects the degree of success of detective fiction as evidenced by its wide dissemination.

In 1992, the London-based Midlayt al-Mahdūda, published, through the Sijill al-'Arab printing house in Cairo, a new series called al-Firqa al-Intihāriyya (The Suicide Unit), authored, again, by Majdī Șābir — a series of adventures filled with action and risk-taking. Its heroes are two men and a woman, all members of the Egyptian Intelligence Services. ${ }^{64}$ Likewise, the same publisher put out another new series called Diskūvirī (Discovery)with science fiction adventures, also written by Majdī Șābir. ${ }^{65}$

To crown his new endeavours, Majdī Șābir began in 1992 writing yet another series, also for Midlayt al-Maḥūda, entitled 'Idārat al-Būlìs al-Nisā'̄ - al-Kubrà (Women's Police Administration - Cobra), in which the key roles are played by female police officers who are responsible for the safety of the public and the state in face of all the dangers that lurk. $^{66}$

Yet another series was launched in Amman: Qiṣaṣ Būlīsiyya lil-'Awlād (Detective Stories for Children). Apparently, the name is chosen on purpose: it seems to reflect a desire to replicate the tremendous success in Egypt. ${ }^{67}$ However, this dream did not materialize and the author left Jordan and moved to the USA.

In Syria there was an attempt similar to the one in Jordan. A writer by the name of Suhayl 'Ayyūb wrote a series for children called al-Mughamirūn al-'Arba'a (The Four Adventurers), in analogy to al-Mughamirūn al-Khamsa (The Five Adventurers) by Egyptian author Mạ̣mūd Sālim. ${ }^{68}$

In 1994, Dār al-Shurūq (Cairo and Beirut) published a new series entitled 'Alghāz alShurūq (The al-Shurūq Mysteries), by Maḥmūd Qāsim. The heroes are Habhab and his falcon Rafraf. In each adventure, or 'riwāya', as the author calls it, there is a plot that takes place somewhere else on the globe. It is based on real events (such as wars, combat activities, riots...) which the author uses for the setting of the mystery and the ensuing events. $^{69}$ In 1996, the same publisher and author put out a new series entitled Khayā fi Khayāl (Imagination x Imagination), a fantasy set in an imaginary world full of virtue. ${ }^{70}$

Again in 1994, Dār al-'Amīn in Cairo published a new adventure series, al-Qannāṣ alMuhtarif (The Professional Sniper). Its hero is an Egyptian intelligence officer of a special kind, as described by author Majdī Șābir. ${ }^{71}$ The same author wrote a series called

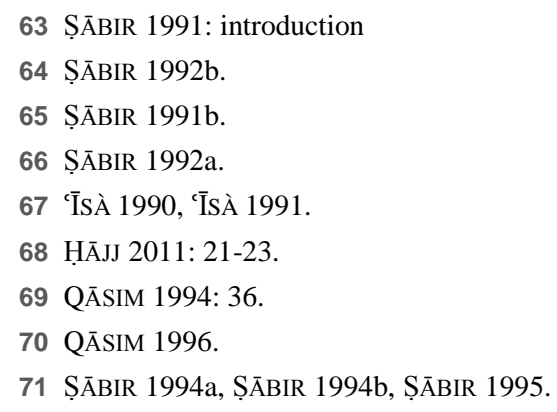


Mughāmarāt fì 'l-Fad̄ä' wa'l-Khayāl al-'Tlmī (Adventures in Space and Science Fiction), published by Dār al-Maārif, It is worth noting that the level of linguistic and printing quality was superior to its other published series. ${ }^{72}$

Also in 1994, Dār Nahḍat Mișr lil-Ṭibā'a wa'l-Nashr wa'l-Tawzī' in Cairo published a series called 'Álam al-Jarima (The World of Crime) which presented crime on three levels: Interpol cases, espionage, and crimes of passion. Some of these crimes were translated (from general world literature...) by Suhayr al-Bīlî, with a preface in Arabic by Maḥmūd Sālim, the ground-breaking pioneer of this genre, while the second part was originalwritten by Maḥmūd Sālim himself. ${ }^{73}$

From that same publishing house and in that same year, there is a new series with the grandiose name of Mughāmarāt al-Qarn al-Qādim (Adventures of the Next Century), written by Rajā' 'Abd Allāh. ${ }^{74}$ It is interesting that the name of the main character, chief scientist Nadīm Șabrī, is very similar to the name of the hero in The Man of the Impossible series, 'Adham Sabrī. We believe this is no coincidence, but rather an attempt to imitate the outstanding success of al-Mu'assasa al-'Arabiyya al-Haditha. Another interesting fact is that the name of Rajā' 'Abd Allāh reappears in more than one series at different times and for different publishers. Thus, it appears, the growing momentum of writing led to situations in which a writer might be writing different series for different publishers, thus actually competing with him/herself. We believe there are also reciprocal influences and a desire to emulate what has already been successful, in the interest of assuring commercial gain.

Also in 1994, Dār al-Bashīr in Amman published a new adventure series entitled 'Alghäz Bülīsiyya lil-Fityān wa'l-Fatayāt (Detective Mysteries for Boys and Girls), written by 'Amal 'Izz al-Dīn. Its heroes are five adventurers. ${ }^{75}$

In 1996, Dār Hātyīh published in Cairo a series called Rajul al-Faḍa $\bar{a}^{\prime}$ (The Space Man), a detective adventure and science fiction by Hiusām al-'Aqqād. Among the newest series we found that in 1998, al-Dār al-Mișriyya al-Lubnāniyya published in Cairo a science-fiction series entitled Fursān al-Ghad (The Knights of Tomorrow), written by Hishām al-Ṣayyād. These were more like regular books in size and volume than the familiar pocket books of similar series, with better quality paper, and a harder coloured cover. In the preface the author writes:

with scientific progress, a group of people has appeared from all over the world, who have a tendency to exploit the dark side of science, trapped in a love of destruction, sabotage and bloodshed, using technology to attain their goals... [...] so it was necessary to think about setting up a well-trained science team with exceptional skills to stop these criminals, and because of the important and active

\footnotetext{
72 ȘĀBIR 1994c, ȘĀBIR 1994d.

$73 \mathrm{Al}-\mathrm{B} \bar{l} l \overline{1}$ [n.d.]a, and SĀLIM [n.d.]e.

74 'ABD ALLĀH 1995.

75 'IZZ al-Dīn 1994.
} 
role Egypt plays in safeguarding the region and the world, this team was set up in our beloved country. ${ }^{76}$

In 2004, Dār Hāla published a new series entitled al-Fursān al-Thalātha (The Three Knights), written by Hishām al-Ṣayyād. Its heroes are Nūra, Māzin and Mukhtār, who, in each issue, try to solve a very puzzling mystery. What is special about this series is that the author does not give the reader clear answers, but rather ends each issue with one or more questions for the reader to think about until the next issue, which contains the solution. This method is reminiscent of the early days of Mạ̣mūd Sālim, before the series of alMughämirūn al-Khamsa (The Five Adventurers), when he used to write two pages on a regular basis for the newspaper, asking the readers to send in their answers and solutions. ${ }^{77}$

In 2005, Dār al-'Isrā' lil-Nashr wa'l-Ṭibā'a published a series entitled 'Ajmal Qiṣaṣ alMughāmarāt al-Khayāliyya lil-'Atfāl (The Most Beautiful Imaginary Stories for Children), ${ }^{78}$ a bi-lingual Arabic-English series with fairy tales, tales of courage, history and science fiction written by Niḍal al-Bazm, ${ }^{79}$ who, in the introduction, writes:

The pages of this book contain imaginary stories about the defense of the planet, or a town or a village against foreigners or aliens, in order to instill love of the country and of others in the souls of our beloved young ones. ${ }^{80}$

In Cairo, Dār al-Ṭalā'ic $i^{\complement}$ published an adventure series entitled al-'Alghāz al-'Ilmiyya (The Scientific Mysteries) written by Fatḥ̄ Șabrī. In this series, three young adventurers, Hasan, 'Amīn and 'Ādil, solve detective mysteries related to science, similar to the first series written by Maḥmūd Sālim. ${ }^{81}$

Another series published by Dār Laylà after 2005 was $S \bar{a}^{\mathrm{c}} \bar{a} t$ al-Khațar (The Hours of Danger), written by Muhammad Sāmī. It had two issues called al-Tajriba al-Mal'ūna (The Cursed Experience) and $a l-R u^{c} b$ al-Qātil (Murderous Horror), in addition to several issues by Dār Laylà, such as:

- Virus - a science adventure series collaboratively written by Tāmir 'Ibrāhīm Tāmir, 'Aḥmad Tāmir Fatḥ̄ and 'Aḥmad Ḥasab al-Nabī.

- $\quad w w w$, a horror series by 'Aḥmad Khālid Tawfīq.

- $\quad$ Al-Mutakhașsișūn (The Experts) by Nabīl Fārūq, which had only three issues.

\footnotetext{
76 Al-ṢAYYĀD 1988: 8.

77 Al-ṢAYYĀD 2004.

78 Al-BAZM 2005.

79 At the end of the book, and in the biography it says that the author has another series entitled Mughāmarāt al-'Abțāl lil-'Atfäl (Heroic Adventures for Children), a name which suggests that it is an adventure series for children, and might also be detective fiction, as is customary in these aeries, it seems. We were unable to actually find this series in the markets.
}

80 Al-BAZM 2005: 3.

81 The adventures actually bear the same name: Lughz al-Dhākira al-Mafqūda (The Mystery of the Lost Memory) and Lughz al-'Awrāq al-Mafqūda (The Mystery of the Lost Papers), see ȘABRī [n.d.]a and ȘABRI [n.d.]b. On the back inside cover it says: 'The series is very powerful: pleasure-culture-action,' see ȘABRī [n.d.]a.

jix • 18 (2018): 23-49 
- Mūlūtūv (Molotov) - "a series that might explode in your hands," as the publisher, Dār Laylà, described it. Writers included 'Ahmmad Khālid Tawfĩq and others.

\subsubsection{Series with no dates}

In addition to the series bearing a publication date, there are also a number of others that show no indication as to when they were published. Among these we note the following series:

- From the Al-Jazīra Library in the Egyptian city of Manșūra, a series entitled alShabah al-'Abyad (The White Shadow), described as 'interesting detective novels' by Dr. Husām al-'Aqqād.

- Mughāmarāt Būlīsiyya lil-'Awlād wa'l-Banāt (Detective Stories for Boys and Girls), by Majdī Șābir, who participated in the writing of several detective and mystery stories and series. Dār Gharīb, printers for the Gharīb library publishers and distributors in Cairo, presented it as 'a monthly series for children combining entertainment, cultural enrichment and pleasure [...] as well as providing ways to think about solving problems that young readers can read but older readers also don't want to give up on.' There were over 30 adventures. ${ }^{82}$

- 'Alghāz 'Ā'ilat Mìm (The Mīm Family Mysteries), by Rajā' 'Abd Allāh. The first pocket book is Mathaf al-Samt (The Museum of Silence), by 'Afāf 'Abd al-Bārī. Subsequent mysteries: al-Kāmīrā al-Khafiyya (The Hidden Camera), al-Kamīn alGhāmiḍ (The Mysterious Ambush), al-'Azhār al-Qātila (The Fatal Flowers), all published by the Gharīb library in Cairo. The stars in these adventures are the members of the Mīm family — father, mother, Hishām, Marwān, Hādiya, Muhșin, the nanny, the driver, Inspector Murād, and $\mathrm{Ra}^{\mathrm{c}} \mathrm{d}$ the dog. The structure and some of the names are similar to those of the earlier mystery series. Hence we assume that this series was published in the late 1970s / early 1980s. ${ }^{83}$ We can see that in this group the names of three adventurers from the series of Detective Stories for Children reappear: Hishām, Muhssin and Hādiya, and the two last ones from the same group. It seems that this frequency is not a coincidence; rather, it demonstrates the process of copying from one series to another. It seems to indicate that it was hard to avoid such a practice, given the drive of the many publishers and the continuity at the start of every month, and the appearance of the same authors' names (e.g. Muhammad Qāsim, Rajā' 'Abd Allāh,'Afāf 'Abd al-Bārī, Maḥmūd Sālim and Majdī Șābir) in other series published by various other publishers. But this quantity of momentum aimed at catering to the increasing demands of the readership, mostly children and adolescents, it seems in hindsight, was one of the main reasons and one of the drivers of innovation and diversification in the writing and the desire to seek novelty in form, style and content.

82 ȘĀBIR [n.d.] see also the list of publications of Dār Gharīb: 119-120.

83 'ABD al-BĀRì [n.d.]a. 
- The Dār Hatyīh publishers in Cairo once again published a series written by 'Afāf 'Abd al-Bārī called Faräfissh. It contained detective riddles, science fiction stories, leisure games, thinking puzzles, jokes, general knowledge and many other sections. ${ }^{84}$

- Al-Mughāmirān (The Two Adventurers), written by Samīr Sarhạn, published and distributed by Nahḍat Miṣr . On the outer cover page of the first issue, bearing the title al-Jarima al-'Iliktrunniyya (The Electronic Crime), it says that this 'is the first of a series of adventures in which the heroes are two brothers who love to help the police uncover the mystery surrounding the (police) detective puzzle, and thus help solve it'. It is worth mentioning the high level of this series, compared to other similar detective series in terms of style, language and the overall quality of the artistic product. ${ }^{85}$

- Rambo, written by 'Amr Yūsuf, was published by the Arab Center for Publication and Distribution in Alexandria, the first publishing house not located in Cairo that we have encountered so far. Rāmbu (Rambo) is a pocketbook adventure series revolving around the character of Rambo, inspired by the character of the American film of that name played by Sylvester Stallone, whose picture is prominently displayed on the cover of each adventure. ${ }^{86}$

- The Safir (The Ambassador), an adventure series written by 'Ashraf al-Sayyid al'Uqbī and published by the Unit for Children's Education, Safîr Co., in Cairo. ${ }^{87}$

\subsubsection{Translated series}

In addition to the series written in Arabic, there are the translated series that added to the panorama of the genre such as The Wheat Sheaves, published by the Global Egyptian Publisher - Longman (1992), containing a variety of adventures such as those of Sherlock Holmes and other thrillers. Some of the pocketbooks were printed by either Nūbār or Dār al-Ma'ârif in Cairo, others by the Global Arab House in Beirut, all showing a high quality of production and finishing, coloured illustrations, some also a fully vowelized text. ${ }^{88}$ Another translated series is Arabic title (Safe Road), published by Dār al-Shurūq (in Cairo and Beirut), mentioning the name of the original author and not the Arabic translator ${ }^{89}$

It is interesting to find that also the Jarîr library in Riyadh, Saudi Arabia, published good quality translated series including:

- Al-Mughāmirūn al-Khamsa (The Famous Five) by Enid Blyton.

- Al-Mukhbirūn al-Sab'a (The Secret Seven) by Enid Blyton.

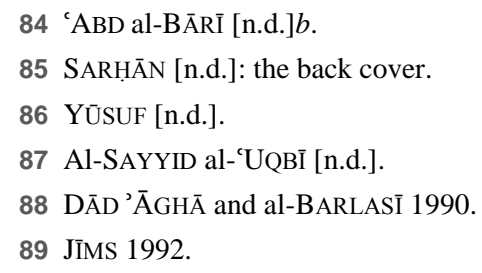


- Silsilat al-'Awläd al-'Aqwiyä' (Hardy Boys). A very powerful series for children by Franklin W. Dixon.

- Silsilat Nānsī Drū al-Mukhbira al-Sirriya (A Nancy Drew series), about a young girl detective who solves mysteries, authored under the pen name of Carolyn Keene.

It is possible that these publications indicate a certain literary shift in which Riyadh and cities in the Persian Gulf states began to focus non-canonical literature, while canonical literature began to develop in Cairo-a possible topic for future research.

Another comic book series in colour published in English by the Marvel Entertainment Group Inc. was translated into Arabic and published by Dār al-Shām lil-Nashr wa'l-Tawzî́c It includes:

- G.I. G.I. Jü (G.I. Joe) - "Thrilling adventures for children and young people," as described by the author ${ }^{90}$

- Thürmān (Thurman) - an all-powerful adventurer, a series "of children's booksthrilling and interesting adventures for children" ${ }^{\prime 1}$

- Sbāydirmān (Spiderman) - "thrilling adventures for boys and girls"92

- Banshir (Bancher) - "thrilling adventures for children and young people"93

- Xmān... (X-man) - "thrilling adventures for children and young people"94

\section{Main themes in the series}

After examining a considerable number of the adventures in the various series written originally in Arabic, we were able to form a general picture of their contents and their main themes. Within the general framework of a struggle of the good heroes against the forces of evil, one can point in the various stories, to a number of topics common to all of them.

\subsection{The presence of the régime}

The political regime has a strong presence and is involved in the smallest details. It is an integral part of the detective force and the plot. Its representatives are characters who influence the chain of events and the progress of the investigation. This presence is expressed in two ways:

a. The character of a security officer (from various forces) who accompanies the young adventurers, guides them and helps them discover the truth.

b. The character of the hero himself, a security officer, is a public servant in one of the units; he pursues the forces of evil that are trying to harm the state. He carries out his missions while serving as a security officer.

\footnotetext{
90 'ABŪ GHAZĀLA [n.d.]a.

91 KAMĀL [n.d.]a: inside cover.

92 KAMĀL [n.d.]b: inside cover.

93 'ABŪ GHAZĀLA [n.d.] $b$ : inside cover.

94 'ABD al-`ĀṬī [n.d.]: inside cover.
} 
What is interesting in these series is that they all have a happy ending. The story ends with all the adventurers or security forces safe and well, while the criminals have a bitter destiny, being caught either by the heroes or by the police. This gives rise to several points:

1. The security forces are far-reaching and get to everyone, anywhere, however smart and cunning they might be. This sends a powerful message about the image of the various security forces or anyone representing them or acting on their behalf.

2. Criminals and villains are never free forever. They might deceive the state or its people, but only for a limited period of time until order is restored. Good always comes out on top. Here, too, one can sense a message that the regime benefits from.

3. In life there is hope that injustice will be righted, justice will be seen to be done. This offers a prime social and religious message. Good vanquishes evil, the angels overcome the devil and his followers in the true spirit of religions.

4. There is no domain in which 'big brother'/the security officer cannot intervene and get what he wants. This creates the feeling that criminals might rule, but nevertheless, they are eventually overruled and will inevitably lose their temporary high standing.

5. When you are helped by the right people, the outcome will always be good. In these series, anyone who has a connection to any kind of government body is good, kind, willing to help and knows how to do so. He has been trained for this.

Hence we see that the theme was enlisted by the writers, inspired by the regime, in order to present a good, peaceful and happy world in which the forces of good always overcome the forces of evil and the regime always cares for the wellbeing of its citizens - at least in the booklets in the hands of the next generation of the seventies of the $20^{\text {th }}$ century.

\subsection{Pan-Arabism and patriotism}

Irrespective of series or subgenre, the hostile forces representing the Evil always come from outside the Arab world (outside Egypt, in particular). They seek to breach the security mechanisms of the local intelligence forces and spread death, destruction and panic among the public, in order to undermine national security and stability. In order to achieve optimal success the offenders use every method and means of espionage they can lay their hands on, armed with all the most sophisticated weaponry and electronic equipment in order to steal defense, military, political or scientific secrets, etc. In the texts, these forces appear in two variants:

a) external forces. These forces may be from different countries and geographical regions. By the frequency of their appearance as well as their way of operating and their aims, they can be further divided into two categories:

- intelligence services from around the world

- the Israeli Mossad

b) hostile forces active within the country

Even in the latter case, the adventurers are helped by agents of the local security forces, who are excellently trained to handle such missions. Thus, the heroes succeed in defeating 
the attempts to spread destruction. Despite the modest means of the Egyptian and Arab security forces, and despite the sophisticated means at the disposal of the attackers, the young Egyptian/Arab adventurers are prepared to stand up against the attackers and prevent them from achieving their aims. It goes without saying that the high self-confidence of the adventurers and the Arab security forces carries the message of Arab unity and victory at any price over the enemy who is lurking inside or outside the country. The enemy thus serves the goal of highlighting the importance of unquestioned general support for the existing Arab regimes, despite all internal problems.

\subsection{The character of the investigator}

Among the investigators three categories can be distinguished:

a) adult investigators. These usually are police officers, detectives or intelligence officers from one of the security forces. The hero is paid by the authorities for whom he works. The motivation to unearth the crime is typically a sense of national-social duty. The task of locating the criminals, pursuing them and bringing them to justice is part of his official job, and he perceives of his activities as such. 'Adham Sabrī from the The Man of the Impossible series is a prime example of this category. ${ }^{95}$

b) The second category is that of the young amateur adventurers. The motives by which they are driven often include a sense of adventure as well as national and social zealotry and concern; some also act out of curiosity and a strong desire to behave like adults and enter into the adult world. Examples of this would be Muhibb, Lūza, Nūsa, 'Ātịf, and Takhtakh, the Five Adventurers of Mahmūd Sālim, or 'Āmir 'Ālya and their cat Mūrjān, the Three Adventurers of 'Abd al-Raḥmān Hamdī. ${ }^{96}$

c) The third category is a combination that falls somewhere between the first two categories. It is found particularly in one of the most widely read series, Majmü ${ }^{c} a t$ al-Shayāțin al-13 lil-Shabāb (The 13 Devils Group for Youngsters). They are 'Aḥmad, 'Uthmān, 'Ilhām, Hudà, Bū-'Umayyir, Miṣbāḥ, Zubayda, Fahd, Khālid, Rīmā, Qays, Bāsim, and Rashīd. They fall between the two other categories because they are all young people from different Arab countries, full of energy and curiosity, like those in the second category; at the same time, they work officially for a joint Arab intelligence service headed by a mysterious leader called 'Number X', an adult intelligence officer, like those in the first category. ${ }^{97}$

\subsection{Equality-women fighting alongside the men}

The girl or woman detective, as she appears in the various series, is very different from the stereotype of the Arab woman who is harnessed to her husband and cannot be an entity capable of living an independent life without the protection of her husband. Here it is a

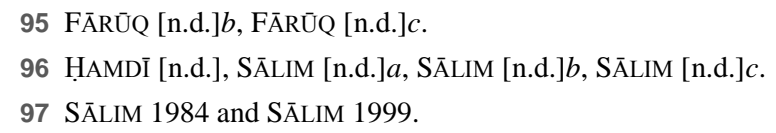


woman of different standards, which sends a different social message. Her antistereotypical behavior provides a very obvious and prominent gender aspect. We can see her through a different gender lens: she thinks, she fights, she is strong and getting stronger; she plays a key role and is a partner in the decision-making and execution of the tough and dangerous missions; she is the man's equal and committed to the values that were until now considered the purview of men only, such as fighting the enemy and putting oneself in danger for the sake of one's country and homeland. The detective story is one of the domains in which the woman can act to effect gender equality, and in this story she advances and reaches areas that used to be a male monopoly.

\section{Conclusion}

In 2011, al-Majalla al-Arabiyya published an article summarizing the atmosphere of the Arab detective genre. The title- “Iḥtifā’ al-Qurrā’ wa-'Ihmāl al-Nuqqād" (Well received by readers, neglected by the critics) - is in line with our impression that the popularity of Arab detective fiction among the readers was never accompanied by critical research, although detective fiction does indeed exist in modern Arab literature and should not be ignored, both quantitatively and qualitatively. This literature appears on two levels: canonical and non-canonical. The latter offers the broadest level of works, but receives an icy welcome from the academic world, where many scholars consider it to be only marginal literature. Thus, research fails to reflect the scope of the phenomenon.

Despite being ignored by academia and research, this literature, especially at the noncanonic level, was extremely widespread among the youth from the 1960s to the 1990s, and continues on a smaller scope as a result of many factors, such as technology that has weakened the amount of reading in general.

In this article, we tried to shed light on the actual existence of non-canonical detective fiction. We traced the development of the genre from the translations of western detective stories through to the establishment of original Arabic detective literature.

As stated, the emphasis was on the non-canonical series, which constitute the vast majority of detective writing in general and the non-canonical detective literature in particular. Certainly, these are not all the series written and published as part of the noncanonical detective genre, but they are the main series we have been able to find during the many years in which we have been monitoring the scene. While we are not the first to address the importance of Arabic detective fiction, we believe that our innovative contribution of the first comrehensive historical mapping of its development and content will serve future scholars as they continue to study this genre in greater depth.

We believe that detective fiction holds a treasure trove of messages and values as we saw in regard to the themes mentioned above. Non-canonical literature was, we believe, a wall of defense for the regimes in Egypt and other Arab states. It is not subversive literature aimed to shock the political order. On the contrary, it is literature in which the members of the regime are an essential part. "Justice" as a key value in society is achieved through the generous help of the regime and its members. In most of the detective series mentioned we find the government persona who plays an important part in resolving the mystery and punishing the perpetrators of the crime. As we saw, all the series stayed away

زحفㄱ • 23-49 (2018) 
from any criminal activity that might lead to blaming the authorities; all the crime scenarios actually justified the existence of the current regime as an active partner in ensuring order, justice and personal safety.

The field is by no means satiated and requires further research.

\section{References}

'ABD AllāH, Muhammad Riḍà. [n.d.]. Hālāat Khāsșa: Hālat Ishtibāh 7. Cairo: al-Mu’assasa al'Arabiyya al-Hadītha.

'ABd AllāH, Rajā'. 1989. Mughāmarāt al-Jīl al-Būlīsiyya (29): Sirr al-Yawm al-Sābic. Beirut: Dār al-Jîl lil-Ṭab' wa'l-Nashr wa'l-Tawzī̄ .

—. 1995. Mughāmarāt al-Qarn al-Qādim (5): al-Sūbir Sūbir mān. Cairo: Nahḍat Miṣr lil-Ṭibāca wa'l-Nashr wa'l-Tawzī'

'ABD al-'ĀṬī, Muhammad. [n.d.]. 'Iks Mān. Cairo: Dār al-Shām lil-Nashr wa'l-Tawzī' .

'ABD al-BĀRĪ, 'Afāf. [n.d.]a. 'Alghāz 'Ā'ilat "Mīm” (2): al-KAmīn al-Ghāmiḍ. Cairo: Maktabat Ghurayyib.

- . [n.d.]b. Farafissh (8). Cairo: Dār al-Nashr Hatiyyi.

—. [n.d.]c. Mughāmrāt al-Jīl al-'Ilmiyya (5): al-Bi'tha al-Mafqūda. Beirut: Dār al-J̄̄l lil-Ṭab` wa'1Nashr wa'l-Tawzì'.

'ABŪ Ghaz̄̄LA, Sac̄ìd. [n.d.]a. Bānshir: Qannāṣ 'Am Farīsa (3). Al-Qāhira: Dār al-Shām lil-Nashr wa'l-Tawzî́.

— . [n.d.]b. Jī. 'Āy. Jū: (3). Al-Qāhira: Dār al-Shām lil-Nashr wa'l-Tawzīc .

'ABŪ al-SA'D, 'Abd al-Ra'ūf . 1994. Al-Ṭifl wa-'Ālamuh al-'Adabiyy. Cairo: Dār al-Ma'ārif.

AdORno, Theodor W., and Jay M. BERnsteIn. 2001. The Culture Industry: Selected Essays on Mass Culture. London and New York: Routledge.

AdORno, Theodor W., and Max HorkHEIMER. 2007. "The Culture Industry: Enlightenment as Mass Deception.” In Redmond \& Holmes (eds.) 2007: 34-43.

AlLEN, Roger. 1984. "An Analysis of the 'Tale of the Three Apples' from The Thousand and One Nights.” In Savory \& Agios (eds.) 1984: 51-60.

'AsĀQLA, 'Ișām. 2008. "al-Khayāl al-'Ilmī Bayn al-'Adab al-Rasmī wa'l-'Adab Ghayr al-Rasmī.” AlKarmil: 'Abhāth fì al-Lugha wa'l-'Adab, 29: 41-72.

— . 2011. Binā̄’ al-Shakhșiyyāt fì Riwāyāt al-Khayāl al-'Ilmī fì al-'Adab al-'Arabī. 'Ammān: Dār 'Azmina.

Ballas, S., and R. SNIR (eds.). 1998. Studies in Canonical and Popular Arabic Literature. Toronto: York Press.

al-BAZM, Nị̣al. (2005). 'Ajmal Qișaș al-Mughāmarāt al-Khayāliyya lil-'Atfāl (1). 'Ammān: Dār al'Isrā' lil-nashr wa'l-Ṭibā'a.

al-BīLī, Zuhayra. [n.d.]a. Min Milaffāt al-'Intirpūl (2): 'Ummī. (n. p.), (n. pub.).

— . [n.d.]b. Min Milaffāt al-'Intirpūl (3): Al-Bārūn al-Muzayyaf. (n. p.), (n. pub.).

CACHIA, Pierre. 1990. "Unwritten Arabic Fiction and Drama." An Overview of Modern Arabic 
Literature, 171-178. Edinburgh: Edinburgh University Press.

CAwelti, G. John. 1976. Adventure, Mystery and Romance. Chicago: Chicago University Press.

Colla, Elliot. 2005. "Anxious Advocacy: The Novel, the Law, and Extrajudicial Appeals in Egypt." Public Culture, 17.3: 417-443.

DĀD 'ĀGHĀ, Khālid, and Hāla al-BARLASĪ. 1990. Al-Sanābil-al-Mughāmarāt al-Muthīra: al-Jāsūs wa-Qiṣaș 'Ukhrà. Cairo: Al-Sharika al-Mișriyya al-'Ālamiyya lil-Nashr-Lūngmān.

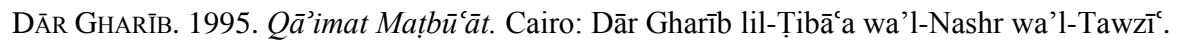

DiMaggio, Paul. (1991). "Cultural Entrepreneurship in Nineteenth-Century in Boston: The Creation of an Organizational for High Culture in America.” In Mukerji \& Schudson (eds.) 1991: 373-397.

FĀRŪQ, Nabīl. [n.d.]a. Fāris al-'Andalus (1): Jāsūsat Qurțuba. Cairo: al-Mu'assasa al-'Arabiyya alHadītha.

— . [n.d.]b. Rajul al-Mustaḥil (6): Qitāl al-Dhi'āb. Cairo: al-Mu’assasa al-'Arabiyya al-Ḥadītha.

— . [n.d.]c. Rajul al-Mustaḥ̄l (9): 'Anyāb al-Thu'bān. Cairo: al-Mu'assasa al-'Arabiyya al-Ḥadītha.

— . [n.d.]d. Milaff al-Mustaqbal (32): 'Ufuq al-'Akhdar. Cairo: al-Mu'assasa al-'Arabiyya al-Hadītha.

— . [n.d.] e. Milaff al-Mustaqbal (129):Warā’ al-'Aql. Cairo: al-Mu’assasa al-'Arabiyya al-Hadītha.

- . [n.d.]f. Mughāmarāt 'Imād wa-'Ulà 'x2' (1): Qaḍiyyat al-Sarrāf. Cairo: al-Mu'assasa al'Arabiyya al-Ḥadìtha.

— . [n.d.]g. Zūm (2): Lughz al-Khizāna al-Khāwiya. Cairo: al-Mu’assasa al-'Arabiyya al-Hadītha.

- . [n.d.]h. Kūktīl: al-Fāris. Cairo: al-Mu’assasa al-'Arabiyya al-Hadītha.

- . [n.d.]i. Silsilat al-'A'dād al-Khāșșa - Rajul al-Mustaḥil: al-Ma'raka al-Kubrà. Cairo: alMu'assasa al-'Arabiyya al-Hadìtha.

GonZalEs-QuiJAnO, Yves. 1998. Les Gens du livre: édition et champ intellectuel dans l'Égypte républicaine. Paris: CNRS Editions.

Guth, Stephan. 2016. "Thus Ruled the Court (Hukm al- 'Adāla).” In SAGASter, StrohmeIER and GuTH (eds.) 2016: 67-92.

ḤĀJJ, 'Ibrāhīm. 2011. "al-Riwāya al-Būlīsiyya fī Sūryā: Malghūma wa-Ghawiyya.” Al-Majalla al'Arabiyya, 412 (Apr. 2011 ): 21-23.

al-ḤALABī, Ḥasan. [n.d.] a. Tāxī: al-Ladhīn Jā’ūu. Al-Qāhira: al-Mu’assasa al-'Arabiyya al-Ḥadītha.

— . [n.d.]b. Tāxī: Mālākān. Al-Qāhira: al-Mu’assasa al-'Arabiyya al-Hadītha.

ḤALī̄ī, Shu'ayb. 2012. Al-Mahkī al-Būlīsiyy fì al-Riwāya Al-'Arabiyya. Al-Dār al-Bayḍā̄: Manshūrāt Mukhtabar al-Sardiyyāt.

Ḥ̂MĀM, Muștafà. [n.d.]. Qișaș Būlīsiyya lil-'Awlād (179): Lughz al-Risāla al-Majhūla. Cairo: Dār alMa'āifif.

ElHamamsy, Walid, and Mounira Soliman (eds.). 2013. Popular Culture in the Middle East and Northa Africa: A Postcolonial Outlook. New York and London: Routledge.

ḤAMDĪ, 'Abd al-Raḥmān. [n.d.]. Qișaș Būlīsiyya lil-'Awlād (92): Lughz al-Kharīta al- 'Ajība. Cairo: Dār al-Ma'ārif.

'ĪsÀ, 'Abd Allāh. 1990. Qiṣaș Būlīsiyya lil-'Awlād (1): Lughz Jabal al-Ashbāḥ. 'Ammān: Dār al'Ibdāc.

— . 1991. Qiṣaṣ Būlīsiyya lil-'Awlād (2): Lughz al-Ṭarḍ al-Mafqūd. 'Ammān: Dār al-’'Ibdāē.

'IzZ AL-Dīn, 'Amal. 1994. 'Alghāz Būlīsiyya lil-Fityān wa'l-Fatayāt (1): lughz al-'Abājūra al-Zarqū'. 'Ammān: Dār al-Bashīr.

jais • 18 (2018): 23-49 
JACQUEMOND, Richard. 2003. Entre scribes et écrivains: Le champ littéraire dans l'Égypte contemporaine. Paris: Sinbad/Actes Sud.

- .2008. Conscience of the Nation: Writers, State, and Society in Modern Egypt / translated by David Tresilian. Cairo: The American University in Cairo Press.

JīMs, Kīnīth, and Jūn 'Alin. 1982. Silsilat al-Salāma 'Ilà al-Kawākib "L”. Beirut: Dār al-Shurūq.

al-JuNDī, 'Anwar. [n.d.]. Khașā'iș al-'Adab al-'Arabī fì Muwājahat Nadhariyyāt al-Naqd al-'Adabī alHadìth. Beirut: Dar al-Kitāb.

KAMĀL, 'Aḥmad. [n.d.]a. Thūrmān-al-Mughāmir al-Jabbār. Cairo: Dār al-Shām lil-Nashr wa'lTawzī'.

— . [n.d.]b. Sbāydir mān: al-Rajul al-'Ankabūt. Cairo: Dār al-Shām lil-Nashr wa'l-Tawz̄̄ê.

KHĀLID, Tawfìq. [n.d.]a. Mā Warā' al-Ṭabīa: 'Ustrat 'Ākil al-Bashar. Cairo: al-Mu'assasa al'Arabiyya al-Hadìtha.

— . [n.d.]b. Safārī: al-Harīq. Cairo: al-Mu’assasa al-`Arabiyya al-Hadītha.

— . [n.d.]c. Fāntāzyā: Khamsatun Minhum. Cairo: al-Mu’assasa al-'Arabiyya al-Hadītha.

— . [n.d.]d. Fāntāayā: Min 'Ajl Țurwāda . Cairo: al-Mu'assasa al-'Arabiyya al-Hadītha.

KHŪRĪ, 'Ilyās. 1982. Al-Dhākira al-Mafqūda. Beirut: Mu'assasat al-'Abhāth al-'Arabiyya.Sabrī, Muḥammad Fatḥī. [n.d.]a. Silsilat al-'Alghāz al-'Tlmiyya (4): Lughz al-Dhākira al-Mafqūda. Cairo: Dār al-Ṭalāìc.

KRīstī, 'Agāthā. (1981). Khātimat al-Ma'sāt. 'Abd al-'Azī 'Amīn (Translator). Cairo: Maktabat Rajab.

al-Majalla al-'Arabiyya. 2011. "Ihtifā̄' al-qurrā̄ wa-'Ihmāl al-Nuqqād." Al-Majalla al-'Arabiyya 412, (Apr. 2011): 14-19.

Malti-Douglas, Fedwa. 1988a. "Classical Arabic crime narratives: Thieves And Thievery In Adab Literature." Journal of Arabic Literature 19: 108-127.

—. 1988b. "The Classical Arabic Detective." Arabica, Tome XXXV (35): 59- 91.

MukerJi, Chandra, and Michael Schudson (eds.). 1991. Rethinking Popular Culture: Contemporary Perspectives in Cultural Studies. Berkeley and Los Angeles: University of California Press.

Mursī, Muḥammad 'Abd al-Ḥalīm. 1995. Al-Thaqāfa wa'l-Ghazw al-Thaqāfì fì Duwal al-Khalīj. Riadh: Maktabat al-'Ibīkān.

MușṬAfÀ, Ḥamdī. [n.d.]. 'Ūskār: al-Qabīla al-Mal'ūna. Cairo: al-Mu’assasa al-'Arabiyya al-Ḥadītha.

MușṬAfÀ, Mușțafà 'Aḥmad. [n.d.]. Qiṣaș Būlīsiyya lil-'Awlād (134). Lughz 'Ulbat al-Nínā'c. AlQāhira: Dār al-Ma'ārif.

PATtERSON-IsKander, Sylvia. 1987. "Arabic Detective Fiction for Adolescents." Children's Literature Association Quarterly: 75-78.

— . 1993. "Arabic Adventurers and American Investigators: Cultural Values in Adolescent Detective Fiction." Children's Literature, 21: 118-131.

QĀSIM, Maḥmūd. 1994. 'Alghāz al-Shurūq: al-Hurūb Dākhil al-Jabal. Beirut: Dār al-Shurūq.

— . 1996. Khayāl x Khayāl: 'A bwāb al-Mustaḥ̄l al-Khamsa. Beirut: Dār al-Shurūq.Al-Saadi, Tania. 2012. "Tree Arabic Novels Starting with a Crime." Middle Eastern Literatures: incorporating Edebiyat. 15/1: 1-19.

Redmond, Sean, and Su Holmes (eds.). 2007. Stardom and Celebrity: A Reader. London: Sage.

SAAD, Mohammed. 2013. "Pioneering children's author Mahmoud Salem dies at 84." Ahram Online. February 25, <http://english.ahram.org.eg/News/65528.aspx>, retrieved February 28, 2013. 
ȘĀBIR, Majdī. 1990. Mughāmarāt Jum'a wa-Shurakā̉ih: Kanz al-Ghafír Shanabū. Cairo: Midlāyt alMaḥdūda.

— . 1991. Diskūvirī (2): Thawrat al-Qurūd. Cairo: Midlāyt al-Mạ̣dūda.

— . 1992. Mughāmarāt Jum'a wa-Shurakā’ih (3): al-Thawr al-Masḥūr. Cairo: Midlāyt al-Maḥdūda.

—. 1992a. 'Idārat al-Būlīs al-Nisā’̀̄ al-Kūbrā: al-Shuratiyya al-Mutawahhisha. Cairo: Midlāyt alMaḥdūda.

— . 1992b. Al-Firqa al-Inthāriyya (17): Jaḥìm al-Qarāṣina. Cairo: Sijill al-'Arab.

— . 1994a. Al-Qannāṣ al-Muḥtarif (1): Mahamma fì al-Jaḥim. Cairo: Dār al-Amīn.

—. 1994b. Al-Qannāṣ al-Muḥtarif (4): ‘Amaliyyat Bārūkh. Cairo: Dār al-Amīn.

- 1994c. Mughāmarāt fì 'l-Faḍā’ wa'l-Khayāl al-'Ilmī (10): Ikhtițāf Fawq al-Qamar. Cairo: Dār al-Ma'ārif.

— 1994 (4). Mughāmarāt fì 'l-Faḍā' wa'l-Khayāl al-'Ilmī (11): Kawkab al-Mutawahhishīn. Cairo: Dār al-Ma ārif.

SABRī, Fatḥ̄i. [n.d.]e. Al-'Alghāz al-'Ilmiyya (5): Lughz al-Dhākira al-Mafqūda. Cairo: Dār al-Ṭalīéa.

SABRī, Muḥammad Fatḥ̄i. [n.d.]b. Silsilat al-'Alghāz al-'Ilmiyya (5): Lughz al-’Awrāq al-Mafqūda. Cairo: Dār al-Ṭalā'ic

Sagaster, Börte, Martin Strohmeier, and Stephan Guth (eds.). 2016. Crime Fiction in and Around the Eastern Mediterranean. Wiesbaden: Harrassowitz.

SĀLIM, Maḥmūd. 1984. Majmū'at al-Shayāținn al-13 (96): Madīnat al-Barākīn. Cairo: Dār al-Hilāl.

— . 1999. Majmū̄at al-Shayâțīn al-13 (285): Rajul bi-lā Wajh. Cairo: Dār al-Hilāl.

—. 1984. Majmū̄at al-Shayāțīn al-13 (96): Madīnat al-Barākīn. Cairo: Dār al-Hilāl.

— . [n.d.]a. Qiṣaṣ Būlīsiyya lil-’Awlād (1): lughz al-Kūkh al-Muhtariq. Cairo: Dār al-Ma'̄ārif.

— . [n.d.]b. Qiṣaṣ Būlīsiyya lil-'Awlād (4): lughz al-Shabah al-'Aswad. Cairo: Dār al-Macārif.

—. [n.d.]c. Qiṣaṣ Būlīsiyya lil-'Awlād (5): lughz al-Manzil Raqam 98. Cairo: Dār al-Māārif.

— . [n.d.]d. Qiṣaș Būlīsiyya lil-'Awlād (6): lughz al-'Alghāz. Cairo: Dār al-Ma'ārif.

—. [n.d.] e. Jarā’im 'Ātifiyya (3): Jarīmat Imra'a 'Ahassat bil-Malal. (n.p.), (n. pub.).

SARHĀĀ, Samīr. [n.d.]. Al-Mughāmirān (1): al-Jarīma al-'Iliktrūniyya. Cairo: Nahụat Miṣr lil-Ṭibā'a wa'l-Tawzì'.

SAvory, Roger M., and Dionisio A. Agios (eds.). 1984. Logos Islamikos: Studia Islamica in Honorem Georgii Michaelis Wickens, Toronto: Pontificial Institute of Mediaeval Studies.

al-SĀwIR̄̄, Abū-Shu'ayb. 2009. "Mufāraqat al-'Intāj wa'l-Talaqqī fī 'l-Riwāya al-Būlīsiyya al"Arabiyya." Fușūl, 76: 69-81.

al-SAYYID al-'UQBī, 'Ashraf. [n.d.] Silsilat Mughāmarāt Safìr(3): al-Mu'āmara al-Kubrà. Cairo: Waḥdat Thaqāfat al-Ṭifl al-'Arabī - Sharikat Safìr.

SELIM, Samah. 2010. "Fictional and Colonial Identities: Arsene Lupin in Arabic." Middle Eastern Literature, 13.12: 191-210.

SHARSHĀR, 'Abd al-Qādir. 2003. Al-Riwāya al-Būlīsiyya. Dimashq: Manshūrāt Ittihād al-Kuttāb al'Arabī.

SHAWQĪ, Sharīf. [n.d.]a. 'Idārat al-'Amaliyyāt al-Khāṣsa: al-Maktab Raqam (19) (5): al-Zilzāl al$R a h \bar{h} b$. Cairo: al-Mu'assasa al-'Arabiyya al-Hadìtha.

Smolin, Jonathan. 2013. Moroccan Noir: Police Crime and Politics in Popular Culture. Bloomington \& Indianapolis: Indiana University Press.

ز 18 (2018) : 23-49 
SNIR, Reuven. 1994. "The Arabic Literature in the Twentieth Century: A Historical functionalDynamic Model." Hamizrah Hehadash, 36: 49-80.

— . 1998. "Synchronic and Diachronic Dynamics in Modern Arabic Literature." In BALLAS \& SNIR (eds.) 1998: 87-121.

— . 2000. "The Emergence of Science Fiction in Arabic literature." Der Islam, 77.2: 263-285.

- .2002. "Science Fiction in Arabic Literature: Translation, Adaptation, Original Writing and Canonization." Arabic Language \& Literature (Seoul), 2: 209-229.

SUlAYMĀN, Nabīl. 2008. Shahrazād al-Mu'āṣira. Beirut: Ittiḥād al-Nāshirīn al-`Arab.

WAȘFī, Ra'ūf. [n.d.]. Nūvā lil-Khayāl al-'Ilmī: Al-Ru'b al-’Iliktrūnī (15). Cairo: Dār al-Màāarif.

Yūsuf, Majd̄̄. 1994. Shakhṣiyyāt Khayāliyya. Shakhșiyyāt Būlīsiyya. Cairo: Manshūrāt al-Ghālī.

YŪSUf, 'Amr. [n.d.]. Rāmbū: Sirr Manājim al-Dhahab. Al-'Iskandariyya: al-Markaz al-'Arabī lilNashr wa'l-Tawzī'.

(C) Basilius Bawardi, Bar Ilan University

४bbawardi@gmail.com
Alif Faranesh, Oranim College $\checkmark$ aleef.f@gmail.com 